\title{
In Vivo Cloning of Arylsulfatase-Tyramine Oxidase Genes in rec Strains of Klebsiella aerogenes
}

\author{
Yoshikatsu Murooka, Masahide OKa, ${ }^{*}$ Mitsuo Yamashita, ${ }^{*}$ \\ Masanori SugiYama and Tokuya HaradA* \\ Department of Fermentation Technology, Faculty of Engineering, \\ Hiroshima University, Saijo, Higashi-hiroshima 724, Japan \\ *Institute of Scientific and Industrial Research, \\ Osaka University, Suita, Osaka 565, Japan
}

Received January 6, 1983

\begin{abstract}
A general, genetic technique for in vivo cloning of bacterial genes is presented. We previously introduced the $\mathrm{Mu}$ phage into various genera of bacteria including Klebsiella aerogenes with RP4:: Mu. Using these strains carrying RP4:: Mu cts and thermo-inducible $\mathrm{Mu}$ prophage in the chromosome, we cloned in vivo the arylsulfatase (ats) and tyramine oxidase (tyn) genes by partial thermo-induction. The donor strains carrying the recombinant plasmids were conjugated with $K$. aerogenes rec strains, which were isolated as UV-sensitive mutants. The resultant recombinant plasmids, pAT1 and pAT2, were purified and used for the transformation of mutant strains deficient in the ats and tyn genes. The ats-tyn genes seemed to be transposed into the RP4::Mu cts plasmid together with other chromosomal DNA fragments. This in vivo cloning method is applicable to a wide variety of gram-negative bacteria.
\end{abstract}

Bacteriophage $\mathrm{Mu}$ and hybrid plasmid RP4 : : Mu can mediate the transfer of chromosomal markers by promoting the formation of plasmid primes or by integration of phage DNA or plasmids into the chromosome to form "intermediate $\mathrm{Hfr}$ " donor strains. ${ }^{1 \sim 3)}$ This property and the development of the transposon $\mathrm{Mu} \operatorname{dl}\left(\mathrm{Ap}^{\mathrm{r}}\right.$ lac $)$ for fusion of genes $^{4}$ indicate that the $\mathrm{Mu}$ genomes and RP4 : : Mu plasmid should be very useful for in vivo genetic engineering.

Previously, Dénarie et al. ${ }^{5)}$ introduced the $\mathrm{Mu}$ phage into strains of Klebsiella and Pseudomonas and we expanded the bacterial host range of coliphage $\mathrm{Mu}$ to most gramnegative bacteria. $\left.{ }^{6}\right)$ By using RP4::Mu, we also created intergeneric recombinant strains of enteric bacteria by transfer of some genes. ${ }^{6}$

By combining the procedure for constructing the RP4:: Mu primes and transformation of the recombinant plasmids to rec strains, we developed a genetic method for in vivo cloning of genes of interest into the RP4: : Mu vector in gram-negative bacteria. This technique does not require in vitro cleavage of the chromo- some or plasmid by restriction enzymes or in vitro ligation of cleaved DNAs.

To illustrate the use of this method, we chose genes involved in the complex system for regulation of sulfate and nitrogen metabolisms in enteric bacteria. In these organisms, arylsulfatase encoded by the ats $A$ gene is repressed by inorganic sulfate or cysteine as a corepressor. This repression is released by expression of the tyramine oxidase genes (tyn), which is induced by tyramine or catecholamines and subject to catabolite and ammonium repressions. ${ }^{7 \sim 9)}$ As a step towards understanding the genetic organization of the ats-tyn region, we isolated clones having the ats-tyn genes in Klebsiella aerogenes by using this method, which will be generally applicable to other bacterial genes and to other RP4 : : Mu-sensitive bacteria.

\section{MATERIALS AND METHODS}

Chemicals and media. The rich media used were Penassay broth (Antibiotic assay medium 3; Difco Labo., Detroit, MI.) and LB medium, consisting of $1 \%$ tryptone 
Table I. List of Bacterial Strains and Plasmids USED AND THEIR CHARACTERISTICS

\begin{tabular}{|c|c|c|}
\hline Strain & Relevant genotype & Source or reference \\
\hline \multicolumn{3}{|l|}{$K$. aerogenes } \\
\hline W70 & Wild-type, $\mathbf{P}^{\mathrm{r}}$ & MacPhee et al. ${ }^{22)}$ \\
\hline MK9000 & $\mathrm{P}^{\mathrm{s}}$ & Streicher et al. ${ }^{23)}$ \\
\hline K204-1 & ats $^{+}$tyn $^{+}$cys pur (RP4:: Mu ctsb̆1) & Murooka et al. ${ }^{8)}$ \\
\hline K204-2 & ats $^{+}$tyn $^{+}$cys pur $\mathrm{Mu}$ cts61 (RP4) & Murooka et al. ${ }^{8)}$ \\
\hline K611 & $\operatorname{tyn} A 611$ & Murooka et al. ${ }^{7)}$ \\
\hline K629 & tynA611 recA29 $\mathrm{srl}^{+}$ & P1 from MKN329 to K642 \\
\hline K642 & tyn A611 srl-2 & Mutagenesis of K611 \\
\hline K646 & $\operatorname{tyn} A 611 \mathrm{srl}-6$ & Mutagenesis of K611 \\
\hline K648 & tyn A611 srl-8 & Mutagenesis of K611 \\
\hline MKN343-1 & tynPA343 tynR4 ats $A 343$ & Oka et $a l^{24)}$ \\
\hline MKN314 & $\mathrm{UV}^{\mathrm{s}} \operatorname{rec} A 14$ & Mutagenesis of MKN343-1 \\
\hline MKN329 & $\mathrm{UV}^{\mathrm{s}} \operatorname{rec} A 29$ & Mutagenesis of MKN343-1 \\
\hline KS291 & $\operatorname{recA29}(\mathrm{pAT} 1)$ & pAT1 transformed to $\mathrm{K} 629$ \\
\hline MT141 & $\operatorname{recA14}(\mathrm{pAT} 1)$ & In vivo cloning in MKN314 \\
\hline MT292 & $\operatorname{rec} A 29(\mathrm{pAT} 2)$ & In vivo cloning in $\mathrm{MKN} 329$ \\
\hline MT431 & tynR4 (pAT1) & pAT1 transformed to MKN343-1 \\
\hline \multicolumn{3}{|l|}{ E. coli } \\
\hline $\mathrm{C} 600-\mathrm{R}$ & hsdR hsdM thr-1 leu-6 thi-1 (RP4) & Kiyohara and Yano \\
\hline BE228 & thr-1 leu-6 thi-1 (RP4:: Mu cts61) & $\mathrm{RaO}^{25)}$ \\
\hline JC5466 & trp his recA56 rps (RP4:: $\mathrm{Mu}$ cts62) & Dénarié $^{5)}$ \\
\hline \multicolumn{3}{|l|}{ Plasmid } \\
\hline RP4 & $\mathrm{Ap}^{\mathrm{r}} \mathrm{Km}^{\mathrm{r}} \mathrm{Tc}^{\mathrm{r}}$ & Kiyohara and Yano \\
\hline $\mathrm{RP} 4:$ : Mu cts61 & containing host chromosome & This paper, $\mathrm{Rao}^{25)}$ \\
\hline $\mathrm{RP} 4:: \mathrm{Mu} c t s 62$ & hybrid of RP4 and Mu cts 62 & This paper, Dénarié et al. ${ }^{5)}$ \\
\hline pAT1 & RP4::Mu cts61-ats ${ }^{+}-t y n^{+}$ & This paper \\
\hline pAT2 & $\mathrm{RP} 4:: \mathrm{Mu} c t s 61-a t s^{+}-t y n^{+}$ & This paper \\
\hline
\end{tabular}

(Difco), $0.5 \%$ yeast extract (Difco), and $0.5 \% \mathrm{NaCl}$. The supplemented LB medium used was LBAKT, LB plus ampicillin (Fujisawa Co., Ltd., Osaka, $100 \mu \mathrm{g} / \mathrm{ml}$ ), kanamycin (Meiji Seika Co. Ltd., Osaka, $25 \mu \mathrm{g} / \mathrm{ml}$ ), and tetracycline (Sigma Chemical Co., St. Louis, MO., $50 \mu \mathrm{g} / \mathrm{ml}$ ). The minimal medium used was $\mathrm{K}$ medium, ${ }^{6}$ consisting of $0.5 \%$ xylose, $0.1 \%$ nitrogen source, $0.1 \mathrm{M}$ potassium phosphate buffer (pH 7.2), $0.01 \% \mathrm{MgCl}_{2} \cdot 6 \mathrm{H}_{2} \mathrm{O}, 1 \mathrm{mM} \mathrm{Na}_{2} \mathrm{SO}_{4}$, and $0.001 \%$ each of $\mathrm{NaCl}, \mathrm{MnCl}_{2} \cdot 4 \mathrm{H}_{2} \mathrm{O}$, and $\mathrm{FeCl}_{3} \cdot 6 \mathrm{H}_{2} \mathrm{O}$. Unless otherwise mentioned, $\mathrm{NH}_{4} \mathrm{Cl}$ was used as a nitrogen source. Media used for isolating clones containing the ats-tyn genes were $\mathrm{XT}(\mathrm{N})$ which consisting of $\mathrm{K}$ medium with tyramine- $\mathrm{HCl}$ as the nitrogen source, and $\mathrm{XT}(\mathrm{N})$ I which was XT(N) containing indoxylsulfate (Sigma Chemical Co., $0.25 \mathrm{mg} / \mathrm{ml}$ ) as an indicator of arylsulfatase. $\mathrm{Ats}^{+}$colonies become blue on plates containing indoxylsulfate. ${ }^{7)}$ For isolating mutants incapable of utilizing sorbitol, sorbitol was used as the carbon source in $\mathrm{K}$ medium ( $\mathrm{KS}$ medium).

Bacterial strains, phage and plasmids. The bacterial strains and plasmids used in this study are described in Table I. The strains of $K$. aerogenes used were derivatives of $K$. aerogenes W70. Transducing phage $\mathrm{Pl}$ lr $100 \mathrm{KM}^{10)}$ and $\mathrm{Mu}$ cts 61 or $\mathrm{Mu}$ cts $62^{6)}$ phage were prepared from our stock cultures of their lysogenes as described previously.

Isolation of mutants. Mutagenesis with $N$-methyl- $N^{\prime}$ nitro- $N$-nitrosoguanidine and chloramphenicol was achieved as described by Sklar. ${ }^{11)}$ The mutagenized cells were treated with penicillin $\mathrm{G}(3,000 \mu \mathrm{g} / \mathrm{ml})$ for $3 \mathrm{hr}$ to achieve enrichment of mutants incapable of utilizing sorbitol. For isolation of $\mathrm{Rec}^{-}$mutants, the mutagenized cells at suitable dilutions were spread on LB plates. After overnight growth, each colony was suspended in $0.5 \mathrm{ml}$ of sterilized saline, and then one loopful of the suspension was patched on two LB plates. One plate was irradiated at $20 \mathrm{~cm}$ for 30 to $50 \mathrm{sec}$ (about $300 \sim 750 \mathrm{erg} / \mathrm{mm}^{2}$ ) with a National UV lamp, model GL-15 (Matsushita Electronics Co., Ltd., Osaka). The plates were then incubated at $30^{\circ} \mathrm{C}$ in the dark for $18 \mathrm{hr}$. Wild-type cells formed a confluent patch of growth, whereas $\mathrm{Rec}^{-} \mathrm{UV}$-sensitive strains formed few, if any, colonies. The UV-sensitive $\left(U^{\mathrm{s}}\right)$ colonies were picked up and streaked to obtain single colonies. These purified $U^{\mathrm{s}}$ colonies were tested for recombination ability by transduction with Plclr100KM phage. 
Transduction. Preparation of Plclr100KM lysates and Pl transduction were performed as described previously. ${ }^{8,10)}$ Pl phages prepared from KM9000 were mixed with UV cells $\left(2 \times 10^{8}\right)$ at a multiplicity of infection of 0.1 . Scoring of $\mathrm{Tyn}^{+}$transductants was done as described previously. ${ }^{7)}$ All strains with $r e c$ mutations were transduced to $s r l$ by mixing $0.1 \mathrm{ml}$ of lysate (about $2 \times 10^{8}$ plaque-forming units $/ \mathrm{ml}$ ) with $2 \times 10^{8}$ cells and plating the mixture on $\mathrm{KS}$ plates. Each $\mathrm{Srl}^{+}$colony was suspended in $0.5 \mathrm{ml}$ of saline, and then one loopful of the suspension was patched on LB plates. After $4 \mathrm{hr}$ of incubation at $30^{\circ} \mathrm{C}$, these plates were placed under a UV-light at a distance of $20 \mathrm{~cm}$ for $30 \mathrm{sec}$. As a control, parent strain $\mathrm{MKN} 343-1$ and $\mathrm{UV}^{\mathrm{s}}$ strains MKN314 and MKN329 were patched on the same plates.

Isolation of clones carrying the recombinant plasmids. For in vivo cloning of the ats and tyn genes, RP4: : Mu cts or RP4 plasmids were used as a vector. K. aerogenes strains K204-1 and K204-2 carrying RP4 : : Mu cts61 and both RP4 and $\mathrm{Mu}$ cts 61 prophages, respectively, were grown overnight at $30^{\circ} \mathrm{C}$ in $5 \mathrm{ml}$ of LBAKT medium. The cells were diluted 1:100 with fresh LB medium. Exponentially growing cells of strains K204-1 and K204-2 were heated at $38^{\circ} \mathrm{C}$ for $16 \mathrm{hr}$ in $\mathrm{LB}$ medium without shaking. This partial induction was mutagenic for the host chromosome and killed about $50 \%$ of the cells. These cells (about $1 \times 10^{9}$ colony-forming units per $\mathrm{ml}$ ) were mixed with an equal volume of recipient cells of strains MKN314 or MKN329 in the late exponential phase of growth in LB medium (about $2 \times 10^{9}$ colonyforming units per $\mathrm{ml}$ ). The mixture was filtered on a Toyo membrane filter $(0.45 \mu \mathrm{m}$ pore size, $25-\mathrm{mm}$ diameter; Toyoroshi Co., Ltd., Tokyo). Membranes were placed on the surface of a freshly prepared Penassay broth plate and incubated at $30^{\circ} \mathrm{C}$ for $5 \mathrm{hr}$. Bacteria were then suspended in $1 \mathrm{ml}$ of saline and samples of 0.1 to $0.2 \mathrm{ml}$ were spread on selective medium $\mathrm{XT}(\mathrm{N})$ or XT(N) I containing Ap $(100 \mu \mathrm{g} / \mathrm{ml}), \mathrm{Km}(25 \mu \mathrm{g} / \mathrm{ml})$, and $\mathrm{Tc}(50 \mu \mathrm{g} / \mathrm{ml})$. Donors were counter-selected by omission of an essential nutrient. In control experiments, donor and recipient cultures were filtered on separate membranes and then incubated and plated under the same conditions as those for mating. The purified colonies grown on $\mathrm{XT}(\mathrm{N})$ were replicated onto $\mathrm{K}$ agar plates in the presence of indoxylsulfate to check arylsulfatase activity, and onto LBAKT and two LB plates, one incubated at $28^{\circ} \mathrm{C}$ and the other at $41^{\circ} \mathrm{C}$. Lysogenes of $\mathrm{Mu}$ cts grew well at $28^{\circ} \mathrm{C}$ but very poorly at or above $39^{\circ} \mathrm{C}$.

Isolation of plasmid DNA. Cells were grown in $50 \mathrm{ml}$ of LB at $30^{\circ} \mathrm{C}$ and harvested in the late exponential phase $\left(2 \times 10^{8}\right.$ cells $\left./ \mathrm{ml}\right)$ by centrifugation. The cells were washed with $25 \mathrm{ml}$ of $10 \mathrm{~mm}$ sodium phosphate buffer $(\mathrm{pH} \mathrm{7.2)}$ and suspended in $1.35 \mathrm{ml}$ of $25 \%$ sucrose- $0.05 \mathrm{M}$ Tris- $\mathrm{HCl}(\mathrm{pH}$ $8.0)$. A cleared lysate was prepared by the alkaline denaturation method of Hansen and Olsen. ${ }^{12)}$ The plasmid DNA was purified by cesium chloride-ethidium bromide equilib- rium density gradient centrifugation in a fixed-angle type 50 rotor at $40,000 \mathrm{rpm}$ at $15^{\circ} \mathrm{C}$ for $40 \mathrm{hr}$. $\mathrm{CsCl}$ was used at a concentration of $1 \mathrm{~g} / \mathrm{ml}$. The plasmid band, located with a UV transilluminator, was collected. Ethidium bromide was removed by extraction with isopropanol saturated with $3 \mathrm{~m}$ sodium chloride and $0.3 \mathrm{M}$ sodium citrate buffer. Cesium chloride was removed by dialysis against $10 \mathrm{~mm}$ Tris- $\mathrm{HCl}$ containing $1 \mathrm{~mm}$ EDTA, $\mathrm{pH}$ 8.0.

Transformation experiments. Transformation was performed as described by Mandel and Higa ${ }^{13)} K$. aerogenes $\operatorname{rec} A$ strains were grown in LB to about $100 \mathrm{Klett}$ units. The cells were harvested and washed once with sterilzed $0.1 \mathrm{M} \mathrm{MgCl}_{2}$ in $5 \mathrm{~mm}$ Tris- $\mathrm{HCl}, \mathrm{pH} \mathrm{7.4}$, suspended in cold $0.1 \mathrm{M} \mathrm{CaCl}_{2}$ and incubated for $20 \mathrm{~min}$ on ice. The suspension was centrifuged and the cells were suspended in onetenth the original volume of cold $0.1 \mathrm{M} \mathrm{CaCl}_{2}$. A $0.2 \mathrm{ml}$ portion of the purified recombinant plasmid DNA was put into an Eppendorf tube containing $0.2 \mathrm{ml}$ of competent cells. The tubes were incubated on ice for $1 \mathrm{hr}$, then warmed to $39^{\circ} \mathrm{C}$ and gently shaken for $2 \mathrm{~min}$. After rechilling, the cells were diluted with fresh $\mathrm{LB}$ and incubated for $6 \mathrm{hr}$ at $30^{\circ} \mathrm{C}$. The cells were plated on XT(N) I containing Ap $(100 \mu \mathrm{g} / \mathrm{ml}), \mathrm{Km}(25 \mu \mathrm{g} / \mathrm{ml})$, and Tc $(50 \mu \mathrm{g} /$ $\mathrm{ml})$.

Electron microscopy. The formaldehyde technique of Lang and Mitani ${ }^{14)}$ was used. The DNA sample $(25 \mu \mathrm{l})$ was mixed with $150 \mu \mathrm{l}$ of $0.15 \mathrm{M}$ ammonium acetate $(\mathrm{pH}$ 7.5), $20 \mu \mathrm{l}$ of cytochrome $c(13 \mu \mathrm{g} / \mathrm{ml})$ and $5 \mu \mathrm{l}$ of $8 \%$ formaldehyde. The layer of cytochrome $c$ with plasmid DNA was picked up on grids of polyvinyl formal coated with carbon, and subjected to staining with uranyl acetate and rotary shadowing with platinum palladium at an angle of $10^{\circ}$. The molecular weight of plasmids was calculated by the equation of Lang ${ }^{15)}$ from measurements on several complete molecules.

Enzyme assay. Arylsulfatase activity was assayed as described previously. ${ }^{\text {7) }}$ One unit of arylsulfatase activity was defined as the amount causing formation of one nanomol of $p$-nitrophenol per min at $30^{\circ} \mathrm{C}$. Tyramine oxidase activity was assayed by a radiometric procedure with $\left[{ }^{3} \mathrm{H}\right]$ tyramine. ${ }^{7)}$ One unit of tyramine oxidase activity was defined as the amount metabolizing one nanomole of tyramine per min at $30^{\circ} \mathrm{C}$.

Protein was determined by the method of Lowry et al. ${ }^{16)}$ with bovine serum albumin as a standard.

\section{RESULTS}

\section{Rationale}

Previously, we created intergeneric recombinant strains by transfer of some genes between $K$. aerogenes and $E$. coli by using $\mathrm{Mu}$ phage and RP4 or RP4: : Mu plasmids. ${ }^{6)}$ At 
least part of the transfer was thought to be due to formation of RP4 prime or RP4::Mu prime episomes, which transfer any genes after induction of $\mathrm{Mu}$ cts prophages on the chromosome, because partial heat induction of $\mathrm{Mu}$ results in formation of $\mathrm{Mu}$-bacterial circular DNA which can be integrated at random into a plasmid. ${ }^{3,26)}$ Thus, we thought that it would be possible to develop an in vivo cloning method for isolating the genes of interest by transposing them into an RP4: : Mu vector in gram-negative bacteria. These clones could be selected in a rec strain with mutations in appropriate genes and verified by transformation of the in vivo constructed plasmid into similar mutant strains.

To demonstrate this method, we isolated plasmids carrying the arylsulfatase and tyramine oxidase genes on RP4: : Mu cts and transferred them to $K$. aerogenes mutant strains deficient in the ats, tyn and rec genes. The working scheme, which consists of five steps, is shown in Fig. 1: (1) RP4 or RP4 : : Mu is introduced into auxotrophic cells containing a $\mathrm{Mu}$ cts prophage or without $\mathrm{Mu}$ prophage, respectively. (2) The Mu cts prophage on the chromosome is partially induced, leading to in

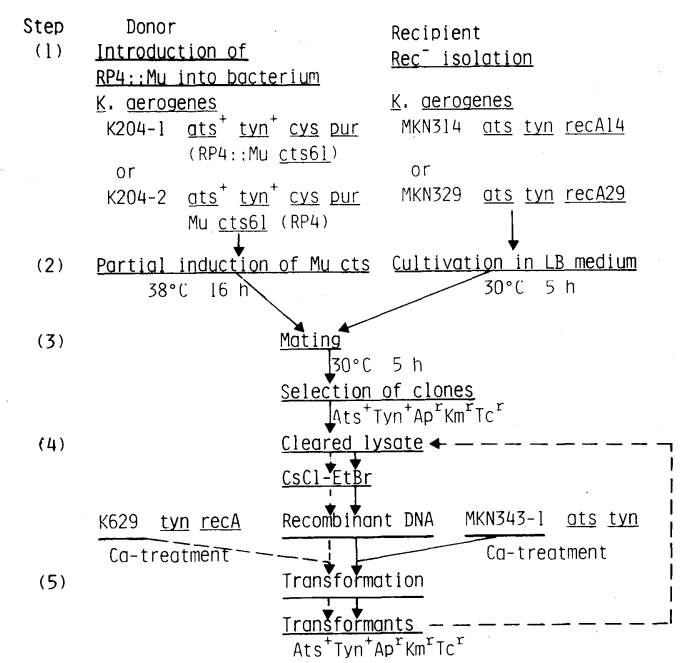

FIG. 1. Scheme of the Method of In Vivo Cloning.

The method consists of five main steps. The details of each step are described in the text. The dotted line shows the second cycle of the process. vivo self-cloning of chromosomal genes. (3) The donor cells are mated with recipient cells carrying mutations of the ats, tyn, and rec genes, and appropriate clones selected. (4) Recombinant plasmid DNA is isolated from the clones. (5) Recombinant plasmid DNA is used to transform secondary recipient cells.

\section{Isolation of rec mutant strains}

Since rec mutations have not been reported in $K$. aerogenes, we tried to isolate mutants of this type. In $E$. coli, at least 6 kinds of rec mutations are mapped in different chromosomal loci. ${ }^{18)}$ Most of these mutations are sensitive to UV irradiation. Therefore, we selected mutants sensitive to UV and tested them for frequency of recombination following transduction by $\mathrm{Pl}$. $K$. aerogenes strain MKN343-1 (tynPA ats $A$ ) was mutagenized with $\quad N$-methyl- $N^{\prime}$-nitro- $N$-nitrosoguanidine and $U^{s}$ colonies were isolated. These puri-

TABLE II. IsOLATION OF $\mathrm{Rec}^{-}$FROM $K$. aerogenes MKN343-1

\begin{tabular}{rrr}
\hline Strain & $\begin{array}{c}\text { UV } \\
\text { sensitivity }\end{array}$ & $\begin{array}{c}\text { No. of } \\
\text { transductants } \\
\text { by Plclr100KM } \\
\text { Tyn }^{+b}\end{array}$ \\
\hline MKN343-1 & R & 4380 \\
MKN314 & S & 0 \\
315 & S & $>4000$ \\
316 & S & $>4000$ \\
323 & S & $>4000$ \\
325 & S & 880 \\
MKN329 & S & 0 \\
330 & S & 4800 \\
331 & S & $>4000$ \\
333 & S & 1116 \\
338 & S & $>4000$ \\
342 & S & $>4000$ \\
343 & S & 1624 \\
356 & S & $>4000$ \\
\hline
\end{tabular}

a $\mathrm{R}$, resistant; $\mathrm{S}$, sensitive.

${ }^{b} \quad$ P1 phages prepared from $K$. aerogenes MK9000 were used at a multiplicity of infection of 0.1 for all transductions. Recipient strains used were derived from strain MKN343-1, which is defective in the tyramine oxidase gene, and used at about 1 to $2 \times 10^{9}$ cells for transduction. The $\mathrm{Tyn}^{+}$phenotype was scored on $\mathrm{XT}(\mathrm{N})$ plates as described previously. $^{8)}$ 
Table III. Genetic Analyses of $K$. aerogenes Rec $^{-}$Strains ${ }^{a}$

\begin{tabular}{|c|c|c|c|c|}
\hline Cross & $\begin{array}{c}\text { Donor } \\
\text { (genotype) }\end{array}$ & $\begin{array}{c}\text { Recipient } \\
\text { (genotype) }\end{array}$ & $\begin{array}{c}\text { No. of } \mathrm{Srl}^{+} \\
\text {transductants tested }\end{array}$ & $\begin{array}{l}\text { No. of } \\
\text { UV s }^{s}\end{array}$ \\
\hline 1 & $\begin{array}{l}\text { MKN314 } \\
\text { (rec-14) }\end{array}$ & $\begin{array}{l}\mathrm{K} 642 \\
(s r l-2)\end{array}$ & 32 & 16 \\
\hline 2 & $\begin{array}{l}\text { MKN314 } \\
\text { (rec-14) }\end{array}$ & $\begin{array}{l}\mathrm{K} 646 \\
(s r l-6)\end{array}$ & 50 & 24 \\
\hline 3 & $\begin{array}{l}\text { MKN314 } \\
\text { (rec-14) }\end{array}$ & $\begin{array}{l}\mathrm{K} 648 \\
(s r l-8)\end{array}$ & 50 & 28 \\
\hline 4 & $\begin{array}{l}\text { MKN329 } \\
\text { (rec-29) }\end{array}$ & $\begin{array}{l}\mathrm{K} 642 \\
(s r l-2)\end{array}$ & 13 & 5 \\
\hline 5 & $\begin{array}{l}\text { MKN329 } \\
(\text { rec-29) }\end{array}$ & $\begin{array}{l}\text { K646 } \\
(s r l-6)\end{array}$ & 50 & 20 \\
\hline 6 & $\begin{array}{l}\text { MKN329 } \\
\text { (rec-29) }\end{array}$ & $\begin{array}{l}\text { K648 } \\
(s r l-8)\end{array}$ & 50 & 21 \\
\hline
\end{tabular}

a P1 phages prepared from strain MKN314 or MKN329 were used at a multiplicity of infection of 0.1 . Scoring of $\mathrm{Srl}^{+}$and $\mathrm{UV}^{\mathrm{s}}$ colonies is described under METHODS.

fied mutants were infected with Plclr100KM phages prepared from wild-type strain MK9000, and $\mathrm{Tyn}^{+}$transductants were selected. Table II shows that $\mathrm{UV}^{\mathrm{s}}$ strains MKN325, 333 and 343 gave low transduction frequencies, and that no transductants of strains MKN314 and MKN329 were obtained. The frequencies of $\mathrm{Pl}$ infection in these $\mathrm{UV}^{\mathrm{s}}$ mutants were not significantly different from that of the wild-type strain MK9000. These strains also gave no $\mathrm{Ats}^{+}$transductants. The transduction frequencies of the two strains were less than $2 \times 10^{-3}$, and both strains were more susceptible to UV irradiation than other $U^{\mathrm{s}}$ stains.

These phenotypic characters of strains MKN314 and MKN329 are similar to that of the E. coli recA mutant, which is $\mathrm{Pl}$ cotransducible with the gene of sorbitol utilization, $s r l .{ }^{18)}$ Thus, we isolated mutant strains that are incapable of utilizing sorbitol from $K$. aerogenes $\mathrm{K} 611(\operatorname{tyn} A)$. We chose three mutants strains, K642, K646 and K648, which showed the $\mathrm{Srl}^{-}$phenotype stably, although most $\mathrm{Srl}^{-}$ mutations were leaky or back-mutated at frequencies of $10^{-6}$ to $10^{-8}$.

We used Plclr100KM to determine the linkages of rec-14 and rec-29 to the $\mathrm{srl}$ genes in strains MKN314 and MKN329, respectively. Table III shows the results of transduction experiments. The $\mathrm{Rec}^{-}$phenotype was scored as UV-sensitivity. The resultant UV transductants were chosen at random and shown to have the $\mathrm{Rec}^{-}$phenotype by $\mathrm{Pl}$ transduction for the tyn $A$ gene. When strain MKN314 (rec14) or MKN329 (rec-29) was used as a donor and strain K642 (srl-2), K646 (srl-6) or K648 $(s r l-8)$ was used as a recipient, the rec-14 and rec-29 mutations were shown to be between $50 \%$ and $40 \%$ cotransducible with the $s r l$ gene, respectively. These results suggest that the mutations of rec-14 and rec-29 are similar to recA mutations of $E$. coli, which are located at 58 min on the chromosomal map. ${ }^{18)}$ Thus, these two rec mutations have tentatively been named rec $A$ of $K$. aerogenes.

Isolation of clones carrying recombinant plasmids containing the ats and tyn genes

$K$. aerogenes auxotrophic strains carrying a thermoinducible Mu prophage on the chromosome and RP4 or RP4::Mu cts61 in the cytoplasm were partially heat induced at $38^{\circ} \mathrm{C}$ for $16 \mathrm{hr}$ and then mated with $K$. aerogenes recipient strains. The recipient strains had a deletion of the structural gene for tyramine oxidase $(\operatorname{tyn} P A)$, were arylsulfatase deficient (atsA), $\operatorname{rec} A$, and were sensitive to $\mathrm{Ap}, \mathrm{Km}$, and Tc, whereas RP4 in the donor confers resistance to Ap, Km, and Tc. The colonies 
TABle IV. Isolation of Clones CARrying RP4 :: Mu-ats ${ }^{+}-t y n^{+a}$

\begin{tabular}{|c|c|c|c|c|c|c|}
\hline \multirow[b]{2}{*}{$\begin{array}{l}\text { Donor } \\
\text { strain }\end{array}$} & \multirow[b]{2}{*}{$\begin{array}{l}\text { Recipient } \\
\text { strain }\end{array}$} & \multicolumn{5}{|c|}{ No. of clones } \\
\hline & & $\begin{array}{c}\text { Selected } \\
\text { maker } \\
\text { Tyn }^{+}\end{array}$ & $\begin{array}{c}\text { Unselected } \\
\text { maker } \\
\text { Ats }^{+}\end{array}$ & $\begin{array}{l}\text { Grow } \\
28^{\circ} \mathrm{C}\end{array}$ & $\begin{array}{l}\text { th at } \\
41^{\circ} \mathrm{C}\end{array}$ & $\begin{array}{c}\text { Drug } \\
\text { resistance } \\
\text { Ap Km Tc }\end{array}$ \\
\hline K204-1 & None & 0 & & & & \\
\hline K204-1 & MKN314 & 5 & 4 & 5 & 0 & 5 \\
\hline K204-1 & MKN329 & 4 & 4 & 4 & 0 & 4 \\
\hline K204-2 & None & 0 & & & & \\
\hline K204-2 & MKN314 & 1 & 1 & 1 & 0 & 1 \\
\hline K204-2 & MKN329 & 1 & 1 & 1 & 0 & 1 \\
\hline None & MKN314 & 0 & & & & \\
\hline None & MKN329 & 0 & & & & \\
\hline
\end{tabular}

a Bacterial strains carrying RP4::Mu cts61 or RP4 and Mu cts61 prophage in the chromosome were partially induced at $38^{\circ} \mathrm{C}$ for $16 \mathrm{hr}$ and mated with $K$. aerogenes strains carrying ats, tyn and rec. The resultant Tyn ${ }^{+}$ colonies were replicated onto $\mathrm{K}$ plates containing indoxylsulfate and tyramine, LB plates containing Ap, Km and $\mathrm{Tc}$, and onto two plates, one incubated at $28^{\circ} \mathrm{C}$, and the other at $41^{\circ} \mathrm{C}$. Lysogens of $\mathrm{Mu} c t s$ grew well at $28^{\circ} \mathrm{C}$, but very poorly at $41^{\circ} \mathrm{C}$.

were purified on $\mathrm{XT}(\mathrm{N})$ plates and replicated on $\mathrm{K}$ plates containing indoxylsulfate and tyramine, LB plates with Ap, Km, and Tc, and on two LB plates without an antibiotic, one incubated at $28^{\circ} \mathrm{C}$, and the other at $41^{\circ} \mathrm{C}$. Arylsulfatase positive colonies gave a blue color with indoxylsulfate. Ten of the 11 colonies isolated as the $\mathrm{Tyn}^{+}$phenotype were $\mathrm{Ats}^{+}$, and all the $\mathrm{Tyn}^{+}$colonies of $K$. aerogenes strains MKN314 and MKN329 carried RP4: : Mu cts, even when strain K204-2 (RP4) $\mathrm{Mu} c t s$ was used as a donor (Table IV). Incorporation of the ats and tyn genes into the RP4 plasmid may be mediated by $\mathrm{Mu}$ promoted transposition, resulting in the construction of RP4: : Mu-ats ${ }^{+}-t^{+} n^{+}$.

\section{Transformation of the recombinant plasmids into $K$. aerogenes}

The resulting colonies probably carrying RP4: : Mu-ats ${ }^{+}-t y n^{+}$were purified by single colony isolation, and two strains, MT141 (recA14, RP4:: Mu cts61-ats ${ }^{+}$-tyn $^{+}$) and MT292 (recA29, RP4: : Mu cts61-ats ${ }^{+}$-tyn $^{+}$), were chosen for isolation of the recombinant plasmids. The plasmids from strains MT141 and MT292 were designated as pAT1 and pAT2, respectively. These plasmids were prepared as described in METHODS. The resultant plasmid DNA was introduced into $\mathrm{Ca}^{2+}$. treated $K$. aerogenes strain MKN343-1 (ats tyn). Transformants that showed $\mathrm{Ats}^{+}, \mathrm{Tyn}^{+}$ and resistance to $\mathrm{Ap}, \mathrm{Km}$, and Tc were selected on $\mathrm{XT}(\mathrm{N})$ I plates in the presence of Ap, $\mathrm{Km}$, and Tc. When about $10^{7}$ to $10^{8}$ recipient cells and about $1.0 \mu \mathrm{g}$ of recombinant DNA were used, 5 to 88 colonies of these transformants were obtained per plate. From one of these purified transformants, the recombinant plasmid pAT1 was prepared by the same procedure. The plasmid DNAs were also used to transform $\mathrm{Ca}^{2+}$-treated strain $\mathrm{K} 629$ (tynA recA29), which was constructed by $\mathrm{Pl}$ mediated transduction of the rec $A$ allele of strain MKN329. About 4 to 20 colonies of transformants with $\mathrm{Ats}^{+}, \mathrm{Tyn}^{+}, \mathrm{Ap}^{\mathrm{r}}$, and $\mathrm{Tc}^{\mathrm{r}}$ markers were obtained per plate. These results show that the recombinant plasmids have both the ats and tyn genes.

\section{Observation of hybrid plasmids by electron microscopy}

The plasmids prepared from $K$. aerogenes were observed by electron microscopy. Figure 2 shows a molecule of pAT1 in the open circular form. Its average molecular weight was calculated to be $80.3 \times 10^{6}$ on determination of its length by electron microscopy 


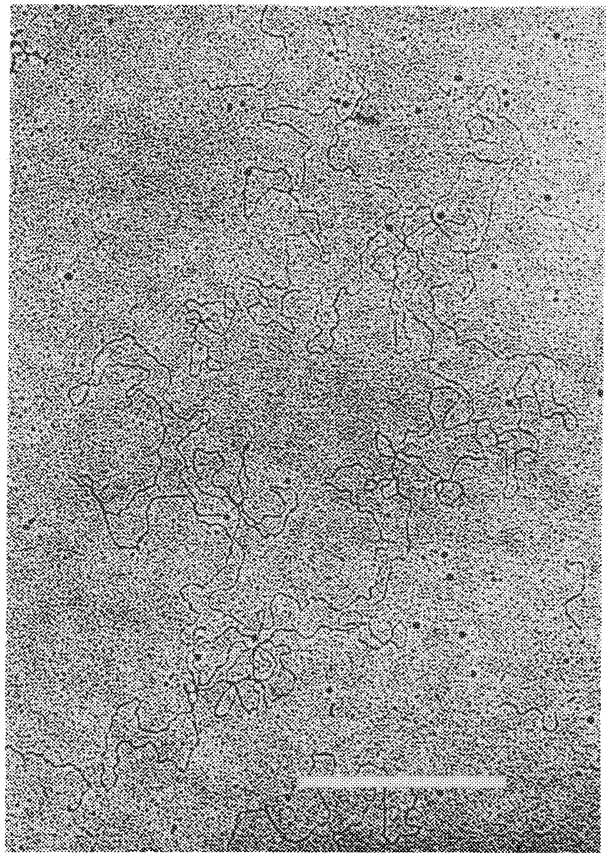

FIG. 2. Electron Micrograph of an Open Circular Molecule of pAT1 Plasmid DNA.

The bar in the frame is equal to $1 \mu \mathrm{m}$.

with plasmid pBR322 as an internal standard. These results agree well with the size of the fragments formed by digestion with restriction enzymes. $^{20)}$

Expression of the ats and tyn genes in the recombinant plasmid

Expressions of the ats and tyn genes of RP4 : : Mu cts-ats ${ }^{+}-t y n^{+}$plasmids in K. aerogenes were investigated. $K$. aerogenes strains KS291, MT141, and MT431, which carry plasmid pAT1 or pAT2, were grown with various sulfur sources and with or without tyramine. The cells were harvested during the exponential phase of growth and assayed for arylsulfatase and tyramine oxidase. As a control, $K$. aerogenes MK9000 without plasmid, and strains MKN314 and MKN329 were cultured under the same conditions. Synthesis of arylsulfatase in strains carrying the pAT1 or pAT2 plasmid was repressed by inorganic sulfate or cysteine as a sulfur source, and this repression was derepressed by addition of tyramine, as shown previously. ${ }^{7)}$ The levels of arylsulfatase in these strains under derepressed conditions were about 4 to 10 units per mg of cells. These levels were similar to or twice that of wild-type strain MK9000. Production of tyramine oxidase in these strains carrying pAT1 or pAT2 was induced by tyramine, and the enzyme levels were 2 to 3 units per $\mathrm{mg}$ of cells. These values were about twice of that of $K$. aerogenes MK9000. No arylsulfatase or tyramine oxidase activity was found in strain MKN314 or MKN329.

\section{DISCUSSION}

This paper describes an in vivo method for construction of recombinant plasmids containing genes from the host chromosome. This method is based on the isolation of RP4 or RP4 : : Mu primes containing a chromosomal fragment due to insertion of $\mathrm{Mu}$ DNA near the gene of interest and transposition of $\mathrm{Mu}$ DNAs with a segment of chromosomal DNA of variable size into RP4 or RP4 : : Mu and on subsequent isolation of transconjugants in a rec strain. The recombinant plasmid is isolated and transferred to the cells of interest.

We tested this method by cloning the arylsulfatase and tyramine oxidase genes using a $K$. aerogenes strain carrying RP4:: $\mathrm{Mu}$ cts and rec strains, since in vitro cloning of intergeneric genes in most bacteria is restricted in Japan, and there is not suitable vector in these bacreria. This method depends on the chance of incorporation of the $\mathrm{Mu}$ genome into some neighboring gene and on the frequency of rec $A$-dependent recombinational events between homologous regions of $\mathrm{Mu} \mathrm{DNA}^{1)}$ and of rec $A$-independent transposition of $\mathrm{Mu}$ into plasmid. ${ }^{3)}$ Since Mu-promoted mutation occurs at high frequency, [e.g., on average, $2 \%$ of randomly isolated lysogens contain auxotrophic mutations caused by insertion of $\mathrm{Mu}$ $\mathrm{DNA}^{17)}$, we can expect that formation of $\mathrm{Mu}$ promoted plasmid primes also occurs to some extent. The frequencies of in vivo cloning of the ats and tyn genes were approximately $5 \times 10^{-8}$ cells per initial donor. These values include the 
frequencies of formation of plasmid primes containing the genes and of transconjugation into the rec-recipient cells. Since these frequencies are lower than those in our previous report using $\mathrm{Mu}$ lysogenic recipients, ${ }^{6}$ ) zygotic induction might occur when recombinant plasmids are transferred into cells without $\mathrm{Mu}$ prophage. K. aerogenes strain K204-1 carrying RP4 : : Mu cts gave many more clones of genes of ats and tyn than strain K204-2 carrying RP4 in the cytoplasm and $\mathrm{Mu}$ cts on the chromosome. We found that the clones obtained from the latter strain also had $\mathrm{Mu}$ cts in the plasmid. These observations suggest that the transposition of the chromosomal genes into RP4 is also mediated by RP4: : Mu, which has been formed by random insertion of Mu into RP4.

The molecular weight of arylsulfatase in $K$. aerogenes is about $47,000^{19}$ and that of tyramine oxidase is about 100,000 , as determined in preliminary experiments by gelelectrophoresis. Thus, the sum of the two genes is calculated to be about $3 \mathrm{~kb}$. Since the ats and tyn genes are cotransducible (about 80 to $90 \%$ ) by phages of both $\mathrm{PW} 52^{7)}$ and $\mathrm{Pl},{ }^{8)}$ plasmids pAT1 and pAT2 probably contain these genes in the form of RP4:: Mu-ats ${ }^{+}$. $t n^{+}$or RP4::Mu-ats ${ }^{+}-t y n^{+}:: \mathrm{Mu}$. However, we found that RP4: : Mu cts61 plasmids prepared from $E$. coli $\mathrm{BE} 228$ and $K$. aerogenes MK9000 have chromosomal DNA fragments of about $21 \mathrm{~kb}$, whereas RP4: : Mu cts62 prepared from $K$. aerogenes MK9000 does not have any chromosomal DNA and that recombinant plasmids pAT1 and pAT2 also contain the same fragments as those of the $21 \mathrm{~kb}$ fragments of RP4: : Mu cts $61 .^{20)}$ These fragments may be derived from the $E$. coli chromosome because this RP4::Mu cts61 originated from $E$. coli. It is not surprising, however, that we isolated a RP4: : Mu prime having a different form of RP4 : : Mu because the $\mathrm{Mu}$ genome can be integrated into any site of RP4 or can transpose small DNA fragments to RP4::Mu, and further rearrangements might occur during cultivation of cells carrying RP4: : Mu primes. The size of pAT1 was calculated to be about $120 \mathrm{~kb}$ by electron microscopy. The values for pAT1 agree well with the length of DNA molecules estimated from EcoRl and HindIII digestions. ${ }^{20)}$ More detailed restriction analysis and studies on the molecular basis of recombinant formation are in progress.

The levels of arylsulfatase and tyramine oxidase in $K$. aerogenes strains carrying recombinant plasmids pAT1 and pAT2 were not significantly higher than those of the wild-type strain. These results suggest that the copy number of the recombinant plasmid is the same as that of RP4, i.e., one to three copies per chromosome ${ }^{21)}$ if RP4 genes are equally expressed.

Although identification of the $\mathrm{Rec}^{-}$mutant in UV-sensitive strains may be difficult in some bacterial strains without a genetic transfer system, the method described here will be applicable, with some modifications, to a wide variety of genera of bacteria other than Escherichia and Klebsiella, such as Enterobacter, Citrobacter, Salmonella, Proteus, Erwinia, Alcaligenes, Serratia, Agrobacterium, Rhizobium, Pseudomonas, and Acetobacter, since RP4: : Mu can be introduced and the $\mathrm{Mu}$ phage is expressed in these bacteria. ${ }^{6}{ }^{6}$

\section{REFERENCES}

1) H. B. Zeldis, A. I. Bukuhari and D. Zipser, Virology, 73, 289 (1973).

2) M. Falen and A. Toussaint, J. Mol. Biol., 104, 529 (1976).

3) R. M. Harshey and A. I. Bukuhari, Proc. Natl. Acad. Sci. U.S.A., 78, 1090 (1981).

4) M. J. Casadaban, Proc. Natl. Acad. Sci. U.S.A., 76, 4530 (1979)

5) J. Dénarié, C. Rosenberg, B. Bergeron, C. Boucher, M. Michel and M. B. De Bertalmio, "DNA Insertion Elements, Plasmid, and Episomes," ed. by A. I. Bukuhari, J. A. Shapiro and S. L. Adahya, Cold Spring Harbor, New York, Cold Spring Harbor Laboratory, 1977, pp. $507 \sim 520$.

6) Y. Murooka, N. Takizawa and T. Harada, $J$. Bacteriol., 145, 358 (1981).

7) Y. Murooka, T. Adachi, H. Okamura and T. Harada, J. Bacteriol., 130, 74 (1977).

8) Y. Murooka, T. Higashiura and T. Harada, $J$. Bacteriol., 136, 714 (1978).

9) Y. Murooka and T. Harada, J. Bacteriol., 145, 796 
(1981).

10) Y. Murooka and T. Harada, Appl. Environ. Microbiol., 38, 754 (1979).

11) R. Sklar, J. Bacteriol., 136, 460 (1978).

12) J. B. Hansen and R. H. Olsen, J. Bacteriol., 135, 227 (1978).

13) M. Mandel and A. Higa, J. Mol. Biol., 53, 159 (1970).

14) D. Lang and M. Mitani, Biopolymers, 9, 373 (1970).

15) D. Lang, J. Mol. Biol., 54, 557 (1970).

16) O. H. Lowry, N. J. Rosebrough, A. L. Farr and R. J. Randall, J. Biol. Chem., 193, 265 (1951).

17) A. L. Taylor, Genetics, 50, 1043 (1963).

18) B. J. Bachmann and K. B. Low, Microbiol. Rev., 44, 1 (1980).

19) H. Okamura, T. Yamada, Y. Murooka and T.
Harada, J. Bacteriol., 143, 321 (1980).

20) Y. Murooka, N. Takizawa and T. Harada, Abstracts of Papers, 8th International Congress of Microbiology, Boston, Massachusetts, Aug., 1982, p. 147.

21) G. A. Jacoby, A. E. Jacob and R. W. Hedges, J. Bacteriol., 127, 1273 (1976).

22) O. G. MacPhee, I. W. Sutherland and J. F. Wilkinson, Nature, 221, 159 (1969).

23) A. L. Streicher, R. A. Bender and B. Magasanik, J. Bacteriol., 121, 320 (1975).

24) M. Oka, Y. Murooka and T. Harada, J. Bacteriol., 143, 321 (1980).

25) R. N. Rao, J. Bacteriol., 128, 356 (1976).

26) J. A. Shapiro, Proc. Natl. Acad. Sci. U.S.A., 76, 1933 (1979). 